\title{
Indications for Intravitreal Bevacizumab in Ibadan, Sub-Saharan Africa
}

\author{
T.S. Oluleye* and Y. Babalola
}

Retina and Vitreous Unit, Department of Ophthalmology, University College Hospital, Ibadan, Nigeria

\begin{abstract}
Background: Angiogenesis is a contributing factor in some retinal diseases, hence the role of vascular endothelial growth factor (VEGF) as a common pathway in proliferative retinopathies. Bevacizumab has been found to be effective in the treatment of these diseases.

The aim of this study was to review all cases of intravitreal bevacizumab given in the retinal unit of the University College Hospital, Ibadan from July, 2010 to June 2012, pointing out the common indications.

Methods: After obtaining ethical approval from the University College Hospital/University of Ibadan Review Board for the study, all cases of intravitreal injections of bevacizumab recorded in the retinal register during the study period (July 2010 to June 2012) were retrieved. Age, sex, diagnoses and indication for injection were recorded in the data sheet prepared for the study. Results were analyzed using proportions and percentages.
\end{abstract}

Results: A total of one hundred and thirty four injections of bevacizumab were given in the study period. The most common indication was cystoid macular edema from retinal vein occlusion ([26(19.4\%)] followed by wet age related maculopathy [23(17.1\%)] and sickle cell retinopathy [(22(16.4)]. Emerging indications included idiopathic polypoidal choroidal vasculopathy [8(6\%) and retinal macroaneurism with macular edema [6(4.5\%)].

Conclusion: Cystoid macular edema from vascular occlusion and wet age related macular degeneration are the major indications for intravitreal bevacizumab injection in Ibadan.

Keywords: Cystoid macular edema, intravitreal bevacizumab, retinal vein occlusion, sickle cell retinopathy.

\section{INTRODUCTION}

Angiogenesis is a contributing factor in many diseases, hence the role of vascular endothelial growth factor (VEGF) as a common pathway in proliferative retinopathies such as diabetic retinopathy [1] and sickle cell retinopathy [2]. It is an important pathogenetic mechanism in diabetic macular edema [3], neovascular age-related macular degeneration (AMD) [4], cystoids macular edema (CME) from retinal vascular occlusions [5] and retinopathy of prematurity (ROP) [6]. It is also implicated in neovascular glaucoma [7]. VEGF is responsible for endothelial cell proliferation, vascular permeability and ocular inflammation [8]. Ranibizumab and Bevacizumab are both antibodies to VEGF and have been shown to be effective in the management of macular edema and vasoproliferative retinal diseases [9-11].

In developing nations like Nigeria, bevacizumab is preferred to ranibizumab, in view of the cost of the latter. However, the former is used as an off label drug. The recent CATT trial (Comparism of Age related maculopathy Treatment Trial) has demonstrated that both medications have equal efficacy [12]

The aim of this study was to review all cases of intravitreal bevacizumab given in the retinal unit of the

*Address correspondence to this author at the Retina and Vitreous Unit, Department of Ophthalmology, University College Hospital, Ibadan, Nigeria; Tel: +2348023265594; Fax: +234 (2) 241 1768;

E-mail: t_oluleye@yahoo.co.uk university college hospital, Ibadan from July 2010 to June 2012, pointing out the common indications.

\section{METHODS}

After obtaining ethical approval from the University College Hospital/University of Ibadan Review Board for the study, all cases of intravitreal injections of Bevacizumab recorded in the retinal register during the study period (20102012) were retrieved. Age, sex, diagnoses and indication for injection were recorded in the data sheet prepared for the study. Results were analyzed using proportions and percentages.

Method of injection: The injection is usually done in the sterile theater envirounment. After an informed consent, topical tetracaine hydrochloride $0.5 \%$ was instilled to the eye. $1.25 \mathrm{mg}$ of bevacizumab in $0.05 \mathrm{ml}$ was given intravitreally $4 \mathrm{~mm}$ from the limbus in the infero temporal quadrant. Anterior chamber paracentesis was done to reduce the intraocular pressure. Topical Povidone Iodine 5\% was instilled before and after the injection. The patient was reviewed first day post injection, one week and monthly. Slit lamp examination and the intraocular pressure were checked at each visit.

\section{RESULTS}

A total of one hundred and thirty four injections of bevacizumab were given in the study period. The most common indication was cystoid macular edema from retinal vein occlusion followed by wet age related macular 
Table 1. Indications for intravitreal bevacizumab in Ibadan, Sub-Saharan Africa.

\begin{tabular}{|c|c|c|c|c|c|c|}
\hline Indications/Age (Yrs) & $<\mathbf{3 0}$ & $31-40$ & $41-50$ & $51-60$ & $60+$ & Total $(\%)$ \\
\hline Retinal Vein Occlusion + CME & - & - & 2 & 7 & 17 & $26(19.4)$ \\
\hline Sickle cell Retinopathy + Vit. Heam. & 4 & 11 & 3 & 4 & - & $22(16.4)$ \\
\hline Prolif Diabetic Retinopathy +Vit Haem & - & - & 4 & 3 & 6 & $13(9.7)$ \\
\hline Branch Retinal Vein Occlusion + Vit. Haem. & - & - & 2 & 1 & 7 & $10(7.5)$ \\
\hline Idiopathic Polypoidal Choroidal Vasculopathy & - & - & 1 & 2 & 5 & $8(6.0)$ \\
\hline Idiopathic CNVM & - & - & 6 & - & 1 & $7(5.2)$ \\
\hline Neovascular Glaucoma & - & - & 2 & 3 & 2 & $7(5.2)$ \\
\hline
\end{tabular}

$\mathrm{CME}=$ cystoid macular edema; $\mathrm{AMD}=$ age related macular degeneration; $\mathrm{CNVM}=$ choroidal neovascular membrane; Vit. Heam= vitreous haemorrhage; Prolif= proliferative.

degeneration (AMD) and sickle cell retinopathy among others (Table 1).

\section{DISCUSSION}

The most common indication for intravitreal bevacizumab in Ibadan was retinal vein occlusion with macular edema. Retinal vein occlusion is a common presentation to the retinal clinic of the University College Hospital, Ibadan [13]. This may be due to the fact that systemic hypertension, a strong predisposing factor for retinal vein occlusion is on the rise in Nigeria and is the most common medical presentation among Nigerians [14] with the prevalence between $11.2 \%$ [15] and 25\% [16-18]. As retinal vein occlusion is associated with increased levels of Vascular Endothelial Growth Factor (VEGF), macular edema from retinal vein occlusion has been reported to respond well to intravitreal bevacizumab [19]. Grid laser treatment showed visual acuity benefit in branch retinal vein occlusion [20]. Intravitreal triamcinolone acetonide demonstrated transient inconsistent benefit with potential complications [21]. Intravitreal bevacizumab appears to be a safe and effective treatment for macular edema associated with branch retinal vein occlusion, at least in the short term [22-26].

The second common indication for bevacizumab injection was wet age related macular degeneration (AMD). Age related macular degeneration is a significant presentation in Ibadan, sub-Saharan Africa as shown by a recent study [27]. In the western world and Asia, it is the most common indication [28]. Bevacizumab is equally effective as ranibizumab for producing visual improvement as opposed to previous treatments that either stabilizes vision or made vision worse [29].

Sickle cell retinopathy is a significant cause of retinal disease in Ibadan, West Africa. The prevalence of the hemoglobin $\mathrm{S}$ gene in Nigeria is between 20 and 25\% [30, 31]. In Nigeria, Hemoglobin SC produces most of the retinopathic changes with previous studies showing patient's presentation at the late stages of the disease [32-34].
Intravitreal bevacizumab help in clearing vitreous hemorrhage before the administration of adequate laser treatment.

Diabetic retinopathy with vitreous hemorrhage and macular edema are emerging indications in Ibadan. There is a global trend towards increase of the incidence and prevalence of diabetes in Africans due to changing lifestyles [35]. Diabetic retinopathy is now a significant cause of blindness in Nigeria [36, 37]. In June 2010, the diabetic clinical research network (DCRNet) compared the anti VEGF ranibizumab with laser and triamcinolone in a randomised trial and found ranibizumab (at a dose of 0.3 $\mathrm{mg}$ ) to be superior to both laser and triamcinolone either alone or in combination with laser [38]. The RESTORE study showed that Ranibizumab monotherapy or combined with laser provided superior visual acuity gain over standard laser in patients with visual impairment due to diabetic macular edema (DME) [39]. The RESOLVE Study and the READ 2 study also clearly showed that ranibizumab is effective in producing visual gain [40, 41]. Bevacizumab (at a dose of $1.25 \mathrm{mg}$ ), an antiVEGF similar to ranibizumab has also been found to be superior to laser in The BOLT study [42].

Idiopathic polypoidal choroidal vasculopathy (IPCV) is an emerging diagnosis in our center. A study from our center describes the disease as more common in women, presenting with hemorrhagic pigment epithelial detachment (PED) subretinal and breakthrough vitreous hemorrhage [43]. Intravitreal bevacizumab help reduce the height of PED and reduces exudation and hemorrhage but the definitive treatment is Photodynamic therapy (PDT) [44].

Other indications found in the study included Idiopathic choroidal neovascular membrane (CNVM), myopic CNVM, neovascular glaucoma and retinal arterial macroaneurism with exudation involving the macula. All these have been reported to respond well to bevacizumab [45, 46]. We also encountered a case of Coats' disease with massive exudation in a young man. Intravitreal Bevacizumab has been reported to help reduce exudation in coats [47]. 
Procurement and dispensing bevacizumab in developing countries are challenging. A $4 \mathrm{ml}$ vial is 5 times the minimum wage of a worker in Nigeria. The options available include pooling patients together for the injection, however in small centers, the number of patients available may not justify purchasing a vial. The other option is to involve the pharmacy department of the hospital concerned to dispense in tuberculin syringes under strict aseptic process. The risk of endophthalmitis is significant with this option and need to be seriously considered. It is important to remember the cold chain involvement in the dispensing of bevacizumab. Frequent power outages in developing nations may disrupt this chain rendering the drug ineffective. The use of alternative power supply is imperative.

\section{CONCLUSION}

The most common indications for intravitreal bevacizumab in Ibadan from this study included cystoid macular edema from retinal vein occlusion, wet age related macular degeneration and sickle cell retinopathy. In developing countries, eye centers should bear in mind the challenges of dispensing bevacizumab.

\section{LIMITATIONS}

The study being a retrospective study, may be limited by accurate data retrieval from case records.

\section{ACKNOWLEDGEMENTS}

The Eye clinic record staff of the University College Hospital, Ibadan, and the departmental staff are appreciated for their contribution.

\section{CONFLICT OF INTEREST}

The authors confirm that this article content has no conflict of interest.

\section{REFERENCES}

[1] Aiello LP, Avery RL, Arrigg PG, et al. Vascular endothelial growth factor in ocular fluids of patients with diabetic retinopathy and other retinal disorders. N Engl J Med 1994; 331: 1480-7.

[2] Kim SY, Mocanu C, Mcleod S, et al. Expression of pigment epithelium-derived factor (PEDF) and vascular endothelial growth factor (VEGF) in sickle cell retina and choroid. Exp Eye Res 2003; 77(4): 433-45.

[3] Antonetti DA, Barber AJ, Khin S, et al. Vascular permeability in experimental diabetes is associated with reduced endothelial occludin content: vascular endothelial growth factor decreases occludin in retinal endothelial cells. Penn State Retina Research Group. Diabetes 1998; 47(12): 1953-9.

[4] Ciulla TA, Rosenfeld PJ. Antivascular endothelial growth factor therapy for neovascular age-related macular degeneration. Curr Opin Ophthalmol 2009; 20(3): 158-65.

[5] Noma H, Funatsu H, Yamasaki H, et al. Pathogenesis of Macular Edema With Branch RetinalVeinOcclusion and Intraocular Levels of Vascular Endothelial Growth Factor and Interleukin-6. Am J Ophthalmol 2005; 140(2): 256. e1-256.e7

[6] Pierce EA, Foley ED, Smith LEH. Regulation of Vascular Endothelial Growth Factor by Oxygen in a Model of Retinopathy of Prematurity. Arch Ophthalmol 1996; 114(10): 1219-28.

[7] Horsley MB, Kahook MY. Anti-VEGF therapy for glaucoma. Curr Opin Ophthalmol. 2010; 21(2): 112-7.

[8] Kowanetz M, Ferrara N. Vascular endothelial growth factor signaling pathways:therapeutic perspective. Clin Cancer Res 2006; 12: 5018-22.

[9] A Prospective Randomized Trial of Intravitreal Bevacizumab or Laser Therapy in the Management of Diabetic Macular Edema (BOLT Study): 12-Month Data: Report 2. Ophthalmology 2010; 117(6): 1078-86.
[10] Elman MJ, Aiello LP, Beck RW, et al. Diabetic Retinopathy Clinical Research Network. Randomized trial evaluating ranibizumab plus prompt or deferred laser or triamcinolone plus prompt laser for diabetic macular edema Ophthalmology 2010; 117: 1064-77.

[11] Avery RL. Regression of retinal and iris neovascularization following intravitreal bevacizumab. (Avastin). Retina 2006; 26: 352-4.

[12] CATT Research Group, Martin DF, Maguire MG, et al. Ranibizumab and bevacizumab for neovascular age-related macular degeneration. N Engl J Med 2011; 364(20): 1897-908.

[13] TS Oluleye, AI Ajaiyeoba. Retinal diseases in Ibadan. Eye 2006; 20(12): 1461-3.

[14] Ogah OS. Hypertension in sub-Saharan African populations: The burden of hypertension in Nigeria. Ethn Dis2006; 16: 765.

[15] Akinkugbe OO. Non-communicable diseases in Nigeria-final report of a national survey. Lagos: Federal Ministry of HealthNational Expert Committee on Non-Communicable Diseases 1997; pp. 1-12.

[16] The Seventh Report of the Joint National Committee on Prevention, Detection, Evaluation, and Treatment of High Blood Pressure (JNC 7). JAMA 2003; 289(19): 2560-72.

[17] Cooper R, Rotimi C, Ataman S, et al. The prevalence of hypertension in seven populations of West African origin. Am J Public Health1997; 87(2): 160-8.

[18] Bella AF, Baiyewu O, Bamigboye A, et al. The pattern of medical illness in a community of elderly Nigerians. Cent Afr J Med 1993; 39(6): $112-6$.

[19] Campochiaro PA. Anti-vascular endothelial growth factor treatment for retinal vein occlusions. Ophthalmologica 2012; 227(Suppl 1): 30-5.

[20] The Branch Vein Occlusion Study Group. Argon laser photocoagulation for macular edema in branch vein occlusion. Am J Ophthalmol 1984; 98(3): 271-82.

[21] Scott IU, Ip MS, VanVeldhuisen PC, et al. SCORE Study Research Group. A randomized trial comparing the efficacy and safety of intravitreal triamcinolone with standard care to treat vision loss associated with macular Edema secondary to branch retinal vein occlusion: the Standard Care vs Corticosteroid for Retinal Vein Occlusion (SCORE) study report 6. Arch Ophthalmol 2009; 127(9): 1115-28

[22] Rabena MD, Pieramici DJ, Castellarin AA, et al. Intravitreal bevacizumab (Avastin) in the treatment of macular edema secondary to branch retinal vein occlusion. Retina 2007; 27: 41925.

[23] Abegg M, Tappeiner C, Wolf-Schnurrbush U, et al. Treatment of branch retinal vein occlusion induced macular edema with bevacizumab. BMC Ophthalmol 2008; 8: 18.

[24] Figueroa MS, Contreras I, Noval S, Arruabarrena C. Results of bevacizumab as the primary treatment for retinal vein occlusions. Br J Ophthalmol 2010; 94: 1052-6.

[25] Guthoff $\mathrm{R}$, Meigen $\mathrm{T}$, Hennemann $\mathrm{K}$, et al. Comparison of bevacizumab and triamcinolone for treatment of macular edema secondary to branch retinal vein occlusion in pair-matched analysis. Ophthalmologica 2010; 224: 319-24.

[26] Wu L, Arevalo JF, Berrocai MH, et al. Comparison of two doses intravitreal bevacizumab as primary treatment for macular edema secondary to branch retinal vein occlusions: results of the Pan American Collaborative Retina Study Group at 24 months. Retina 2009; 29: 1396-403

[27] Oluleye TS. Is Age related macular degeneration a problem in Ibadan, Sub Sahara Africa? Clin Ophthalmol 2012; 6: 561-4.

[28] Li X, Hu Y, Sun X, et al. Bevacizumab for Neovascular AgeRelated Macular Degeneration in China. Neovascular Age-Related Macular Degeneration Treatment Trial Using Bevacizumab Study Group. Ophthalmology 2012; 119(10): 2087-93.

[29] The CATT Research Group. Ranibizumab and bevacizumab for neovascular age-related macular degeneration. N Engl J Med 2011; 364: 1897-908

[30] Oforofuo IA, Adedeji MO. Effect of the sickle cell gene expression on plasma cholesterol in a Nigerian population. Clin Biochem 1994; 27: 505-8.

[31] Akinyanju OO. A profile of sickle cell disease in Nigeria. Ann N Y Acad Sci 1989; 565: 126-36. 
[32] Hassan AO, Oderinlo O, Okonkwo O, et al. Pattern of retinopathy seen in sickle cell retinopathy patients at eye foundation hospital Lagos. Niger J Ophthalmol 2005; 13(1): 17-20.

[33] Akinsola FB, Kehinde MO. Ocular findings in sickle cell disease patients in Lagos. Niger Postgrad Med J 2004; 11(3): 203-6.

[34] Eruchalu UV, Pam VA, Akuse RM. Ocular findings in children with severe clinical symptoms of homozygous sickle cell anaemia in Kaduna, Nigeria. West Afr J Med 2006; 25(2): 88-91.

[35] King H, Aubert RE, Herman WH. Global burden of diabetes, 19952025: prevalence, numerical estimates, and projections Diabetes Care 1998; 21: 1414-31

[36] Nwosu SNN. Diabetic Retinopathy in Nnewi, Nigeria. Nig J Ophthamol 2000; 8(1): 7-10.

[37] Nwosu SNN. Low vision in Nigerians with diabetes mellitus. Doc Ophthalmol 2000; 1: 101(1): 51-7.

[38] Elman MJ, Aiello LP, Beck RW, et al. Diabetic Retinopathy Clinical Research Network. Randomized trial evaluating ranibizumab plus prompt or deferred laser or triamcinolone plus prompt laser for diabetic macular edema. Ophthalmology 2010; 117: $1064-77$.

[39] The RESTORE study: ranibizumab monotherapy or combined with laser versus laser monotherapy for diabetic macular edema Ophthalmology 2011; 118(4): 615-25.

[40] The RESOLVE study group: Safety and Efficacy of ranibizumab in diabetic macular edema. Diabetes Care 2010; 33: 2399-405.
[41] The READ Study group: The primary end point results for Ranibizumab for edema of the macula in diabetes. Ophthalmology 2009; 116: 2175-81.

[42] A Prospective Randomized Trial of Intravitreal Bevacizumab or Laser Therapy in the Management of Diabetic Macular Edema (BOLT Study): 12-Month Data: Report 2. Ophthalmology 2010; 117(6): 1078-86.

[43] Oluleye TS, Babalola Y. Pattern of Presentation of IPCV IN Ibadan, sub-Saharan Africa. Clin Ophthalmol 2013; 7: 1373-6.

[44] Lai TY, Chan WM, Liu DT, et al. Intravitreal bevacizumab (Avastin) with or without photodynamic therapy for the treatment of polypoidal choroidal vasculopathy. Br J Ophthalmol 2008; 92(5): 661-6.

[45] Desco MC, Mataix J, Garcia-Pous M, et al. Combined therapy: photodynamic therapy and bevacizumab to treat myopic neovascular membranes. One-year follow-up. Retina 2011; 31(3): 475-81

[46] Moon SJ, Kim SW, Kim HS, et al. Intravitreal Bevacizumab for Macular Edema Secondary to Ruptured Retinal Arterial Macroaneurysm. J Korean Ophthalmol Soc 2012; 53(4): 522-7.

[47] Ramasubramanian A, Shields CL. Bevacizumab for Coats' disease with exudative retinal detachment and risk of vitreoretinal traction. Br J Ophthalmol 2012; 96(3): 356-9.

(C) Oluleye and Babalola; Licensee Bentham Open.

This is an open access article licensed under the terms of the Creative Commons Attribution Non-Commercial License (http://creativecommons.org/licenses/by-nc/3.0/) which permits unrestricted, non-commercial use, distribution and reproduction in any medium, provided the work is properly cited. 